\title{
Organizational Culture Mediates the Relationship Between Transformational Leadership and Work Outcomes
}

\author{
Laura J. Burton \\ University of Connecticut \\ Jon Welty Peachey \\ University of Illinois
}

\begin{abstract}
The objectives of this study were to examine the mediating effect of group and developmental organizational culture types on the relationship between transformational leadership and three outcome variables-affective organizational commitment, turnover intentions, and job search behaviors. Senior administrators $(n=188)$ working in NCAA Division I intercollegiate athletic departments completed a survey assessing perceptions of leadership behavior of their athletic directors, the culture of their athletic departments, and their affective organizational commitment, turnover intentions, and job search behaviors. Results indicate that group culture partially mediates the relationship between transformational leadership and affective organizational commitment, and fully mediates turnover intentions and job search behaviors. Developmental culture partially mediates affective organizational commitment but has no influence on turnover intentions and job search behaviors. Findings contribute to the understanding of the important mediating role of organizational culture on the relationship between transformational leadership and outcome variables in the intercollegiate athletics context.
\end{abstract}

Financial stability remains one of the most significant challenges facing most intercollegiate athletic departments (Lawrence, 2013). Athletic program costs have continued to rise (Fulks, 2011) while departments face pressures to become more self-sustaining (Martinez, Stinson, \& Jubenville, 2011). Though human capital is considered one of the most valuable assets to sport organizations (Cunningham \& Sagas, 2004; Woo \& Chelladurai, 2012), intercollegiate athletics is noted for

Burton is with the Department of Educational Leadership, University of Connecticut, Storrs, CT. Welty Peachey is with the Department of Recreation, Sport and Tourism, University of Illinois, Champaign, IL. Address author correspondence to Laura Burton at laura.burton@uconn.edu. 
having high rates of employee turnover (Wells \& Welty-Peachey, 2011). The costs associated with recruiting, training, and hiring new employees can be very costly for an organization (Cascio, 2000). Employee retention, therefore, serves as a key factor in helping control operational costs.

Leadership and organizational culture are linked to employee commitment and intention to stay within an organization (Hartnell, Ou, \& Kinicki, 2011; MacIntosh \& Walker, 2012). However, there is limited research within an intercollegiate athletics context that has examined the relationship between leadership and organizational culture and the influence of this relationship on employee commitment and retention (see Wallace \& Weese, 1995; Weese, 1995; Welty Peachey, Bruening, \& Burton, 2011). This is surprising, as Schein (1988) suggests, "the only thing of real importance that leaders do is to create and manage culture" (p. 2). Further, the culture of an organization has an impact on the development of its leaders (Bass \& Avolio, 1993; Schein, 1992).

As MacIntosh and Walker (2012) note, "while research outside of sport has illuminated the idea that organizational culture does matter in terms of employee recruitment and retention, research in sport has only tautologically advanced our understanding of the topic" (p. 114). Leadership remains one important factor not fully examined. If, as Schein (1988) remarks, leadership is critical to establishing and maintaining organizational culture, it would seem logical to investigate how leadership and culture in intercollegiate athletics are related to outcomes of interest. Investigating how leadership and organizational culture can best support employee outcomes will provide additional insights into how to reduce employee turnover and improve organizational performance for intercollegiate athletic departments. Therefore, the purpose of this study was to investigate the mediating effect of organizational culture on the relationship between transformational leadership and three outcome variables - affective organizational commitment, turnover intentions, and job search behaviors.

\section{Theoretical Framework}

\section{Transformational Leadership}

Leaders develop a vision and a direction for the firm, and then align people by communicating the vision and inspiring them to overcome challenges in pursuit of organizational goals (Klimoski \& Koles, 2001). This suggests there is a relationship between leadership, organizational performance, and other organizational outcomes. Leadership research since the mid-1980s has centered on transformational leadership theory (Judge \& Piccolo, 2004). Transformational leadership is visionary and appeals to the higher order psychological needs of employees of feeling valued and worthwhile in the organization (Bryman, 1992). By contrast, a transactional leader manages by contract and reward, promising rewards for good performance (Bass, 1985). The most frequently cited measure of transformational leadership (Eagly, Johannesen-Schmidt, \& van Engen, 2003) is the Multifactor Leadership Questionnaire 5× (MLQ_Form 5×, Bass \& Avolio, 2000), which uses five dimensions to evaluate transformational leadership behavior: idealized influence-attributes, idealized influence-behavior, inspirational motivation, intellectual stimulation, and individualized consideration. Idealized influence-attributes refers 
to the qualities that motivate respect and pride from association with the leader; idealized influence-behavior is when the leader communicates values, purpose, and the importance of the organization's mission; inspirational motivation refers to the leader exhibiting optimism and excitement about goals and the future; intellectual stimulation occurs when a leader examines new perspectives for solving problems and completing tasks; and individualized consideration describes the focus of a leader on development and mentoring of followers and giving attention to their individual needs (Bass \& Avolio, 2000).

Leaders enacting transformational leadership influence extra efforts on the part of followers (Burton \& Peachey, 2009; Rowold, 2006; Welty Peachey \& Burton, 2011); greater satisfaction with the leader among followers (Burton \& Peachey, 2009; Welty Peachey \& Burton, 2011); and enhanced follower perceptions of leader effectiveness (Doherty \& Danylchuk, 1996). Transformational leadership is also associated with job satisfaction among followers (Choi, Sagas, Park, \& Cunningham, 2007; Davis, 2002; Yusof \& Shah, 2008); altruistic behavior among intercollegiate coaches (Choi et al., 2007); affective commitment on the part of intercollegiate coaches and personnel (Choi et al., 2007; Kent \& Chelladurai, 2001); and, decreased turnover intentions of assistant intercollegiate coaches (Wells \& Welty Peachey, 2011).

\section{Organizational Culture and the Competing Values Framework}

One of the most distinguishing features between successful and unsuccessful organizations could be the shared understanding among organizational members as to how things are done (MacIntosh \& Doherty, 2005). Every organization has a unique set of values and beliefs that undergird the success or survival of the firm, and which organization members accept, adopt, and act upon while carrying out their work (Colyer, 2000). These values determine the "feel" of the organization that distinguishes it from others, which in turn creates a sense of stability and focus for organizational activities (Deal \& Kennedy, 1988).

Organizational culture, as defined by Schein (1996), is "the set of shared, taken-for- granted implicit assumptions that a group holds and that determines how it perceives, thinks about, and reacts to its various environments" (p. 236). Though there has been debate regarding which comes first, organizational culture or leadership, it is commonly accepted that leadership influences the development of organizational culture, which also has an influence on the further development of leadership (Bass \& Avolio, 1993; Schein, 1992). Furthermore, scholars generally agree that organizational cultures reflect the important values of the founders or leaders of the firm, and that leaders are hence responsible for crafting the vision and purpose of the organization and reinforcing core values and beliefs through their own behavior (Schein, 1991; Weese, 1995; Wilkins, 1983). In addition, leaders can have a significant influence on the maintenance of the existing culture and can influence whether there is a change to the culture of the organization (Bass \& Avolio, 1993). Leadership can be critical to forming a desirable and productive culture (O’Reilly \& Chapman, 1996; Xenikou \& Simosi, 2006).

In general, organizational culture can affect individual attitudes and behaviors, as well as on overall firm performance (Kent \& Weese, 2000; Wallace \& Weese, 1995). Organizational culture has been linked to leadership and job satisfaction 
(Wallace \& Weese, 1995; Weese, 1995); organizational performance, competitive advantage, and effectiveness (Kent \& Weese, 2000; Smart \& Wolfe, 2000); and team winning percentage (Choi \& Scott, 2008). In addition, MacIntosh and Doherty (2010) found that in the fitness industry, organizational culture was related to employee job satisfaction and intention to leave. However, subsequent work by MacIntosh and Walker (2012) indicated that job satisfaction, not organizational culture, influenced employees' intentions to leave within the fitness industry. The inconsistent findings regarding the influence of organizational culture on turnover intentions warrants further investigation.

One of the most recent organizational culture taxonomies is the Competing Values Framework (CVF; Cameron, Quinn, DeGraff, \& Thakor, 2006), modified from Quinn and Rohrbaugh's (1983) competing values model. The original model examined value differences underlying organizational behavior (i.e., the differences in value orientations that individuals and groups have in organizations). The CVF framework balances flexibility and control functions in an organization to arrive at four quadrants and related organizational culture types, and illustrates the different emphasis given to particular values in an organization's culture (Cameron et al., 2006). The CVF culture types includes: (a) group culture, part of the collaborate quadrant; (b) hierarchal culture, part of the control quadrant; (c) rational culture, part of the compete quadrant; and (d) developmental culture, part of the create quadrant (Cameron et al., 2006). Organizations do not simply fall into one quadrant but may have characteristics of more than one cultural type (Cameron et al., 2006). Thus, organizations may have different levels of each of these four cultural types in their cultural profiles (Colyer, 2000).

Group culture values a flexible, yet internal focus, where human resource development is used to achieve cohesion and enhance employee morale. A core belief within a group culture is that the "organization's trust in and commitment to employees facilitates open communication and employee involvement" (Hartnell et al., 2011, p. 679). The group culture is premised on trust, teamwork, employee involvement, and open communication. A focus of group culture is on "building cohesion through consensus and satisfaction through involvement" (Cameron et al., 2006). A rational culture values control and external focus. An organization with a rational culture emphasizes goal setting and competition to achieve productivity and efficiency. The rational culture is production oriented, with rewards and outcomes linked to goals.

The hierarchal culture focuses on internal process and control functions within the organization. In a hierarchal culture, organizations emphasize rules, procedures, and technical knowledge. Control is also valued and is actualized through the management of information and stability in organizational functioning. Within a hierarchal culture, the predominant belief is that employees are best able to meet expectations when their roles in the organization are clearly defined (Hartnell et al., 2011). Finally, a developmental culture focuses on flexible processes, and values an external focus where the organization uses readiness and adaptability to acquire resources and achieve growth. An organization adopting a developmental culture values growth, autonomy, and attention to detail, and is associated with innovative leaders who are risk-takers and maintain an external focus on the environment (Cameron et al., 2006). 
As previously noted, leaders help to establish, shape, and maintain the culture in an organization (Schein, 1992). Within the framework of this study, there is strong theoretical rationale that transformational leadership is associated with group and developmental cultures, more so than with hierarchal and rational cultures. Transformational leaders value relationships, teamwork, and social support (Simosi $\&$ Xenikou, 2010), and through their focus on individualized consideration, give personal attention to employees to help them feel valued and worthwhile (Avolio, Bass, \& Jung, 1999). Thus, a transformational leader will be more likely to establish and maintain a group culture that emphasizes human resource development and quality relationships. A transformational leader is also visionary, creative, and inspiring, encouraging self-actualization and risk taking (Bass, 1999; Simosi \& Xenikou, 2010), which would lend itself to promulgating a developmental culture focused on readiness, flexibility, and adaptability to achieve growth.

Transformational leaders also value relationships and flexibility over status, rules, and procedures; therefore, they would be less likely to establish or maintain hierarchal or rational cultures (Simosi \& Xenikou, 2010). To obtain organizational objectives, transformational leaders are more likely to establish flatter organizational structures and emphasize adaptability and trust rather than rules or procedures (Welty Peachey et al., 2011). Similarly, a transformational leader is likely to view organizational performance and competitive advantage emerging as a result of a strong focus on relationships, values, and trust. Thus, transformational leaders emphasize building relationships to achieve objectives more so than an external orientation toward rational goals and competition (Welty Peachey et al., 2011). Transformational leaders emphasize new perspectives for solving problems and completing tasks. They also develop and mentor followers and provide attention to followers' individual needs. Therefore, such leadership behavior will contribute to and cultivate a culture that is more supportive and developmental rather than a culture emphasizing rules and procedures manifest in a hierarchical culture (Lok et al., 2005). As such, from a mediation standpoint, it is difficult to argue that hierarchal or rational goals cultures would mediate a relationship between transformational leadership and outcome variables, such as the ones examined in this study, because a transformational leader would most likely not establish and maintain these types of cultures. As a transformational leader is more likely to establish and maintain group and developmental cultures, it makes theoretical sense to only examine these culture types as potential mediators of organizational outcomes.

Within sport management, Colyer (2000) used the CVF to study the organizational cultures of Western Australian sport organizations and developed cultural profiles for each organization. Welty Peachey and colleagues (2011) used the CVF to study organizational change in intercollegiate athletics, finding that group and developmental cultures were associated with employee acceptance of change. Furthermore, Choi and Scott (2008) found that within minor league baseball in the U.S., organizations placed an emphasis on developing a rational culture with a focus on goal achievement, as well as a group culture centered upon cohesion and trust. Hence, due to its use, and results emerging from studies within the sport context, we adopted the CVF as both our theoretical and methodological basis for this investigation. 


\section{Organizational Culture as a Mediator Between Transformational Leadership and Affective Organizational Commitment}

Affective organizational commitment is defined as "the employee's attachment to, identification with, and involvement in the organization" (Meyer \& Allen, 1991, p. 67). Affective commitment to an organization appears to be most strongly influenced by transformational leadership behaviors (Choi et al., 2007; Kent \& Chelladurai, 2001). Affective organizational commitment has been conceptually linked to transformational leadership behaviors in athletic administration and collegiate coaching, whereby transformational leadership is positively related to affective organizational commitment (Choi et al., 2007; Kent \& Chelladurai, 2001).

Organizational culture can also influence an employee's affective organizational commitment. Using Wallach's (1983) typology of innovative (values change and entrepreneurialism), supportive (values relationships and collaboration), and bureaucratic (values power and control, centralized and formalized decision-making process) cultures, researchers have observed that innovative and supportive cultures were positively related to affective organizational commitment, while bureaucratic cultures were slightly negatively related to affective organizational commitment (Lok \& Crawford, 1999; Silverthorne, 2004). Lok and colleagues (2005) similarly discovered innovative and supportive cultures had a positive influence on employee affective organizational commitment. In addition, a bureaucratic culture was negatively related to affective organizational commitment because it does not value employee input or feelings (Silverthorne, 2004).

There has been emerging empirical support (although limited) for the mediating influence of organizational culture on leadership behavior and affective organizational commitment. Lok and colleagues (2005) found that innovative and supportive subcultures mediated the influence of consideration leadership (i.e., attentive to employees' needs and to maintenance of relationships) on employees' affective organizational commitment. Further work by Simosi and Xenikou (2010) used humanistic, affiliative, achievement, and self-actualizing culture orientations to examine the relationship between transformational leadership and employees' affective commitment to an organization. Humanistic cultures place an emphasis on teamwork and employees' empowerment, whereas affiliative cultures focus on cooperation and development of interpersonal relationships. Organizations that focus on self-actualizing cultures are characterized by creativity and an emphasis on both task accomplishment and individual growth at the same time. Their findings indicated that humanistic, affiliative, and self-actualizing cultures mediated the relationship between transformational leadership and employees' affective commitment to an organization (Simosi \& Xenikou, 2010).

Within an intercollegiate athletic department, if the athletic director demonstrates transformational leadership, she or he will inspire a sense of confidence and high expectations in employees, which may foster positive group norms including social support, teamwork, and goal achievement (Welty Peachey et al., 2011). These group norms will in turn support the values of teamwork, open communication, and trust as espoused in a group culture and help keep employees committed to the organization. Therefore, we propose the following hypothesis: 
Hypothesis 1a: Group culture mediates the relationship between transformational leadership and employee affective organizational commitment.

Further, a leader demonstrating transformational leadership behaviors will encourage employees to be creative and innovative, and challenge employees' beliefs and values (Welty Peachey et al., 2011). This leadership will support the values of autonomy, creativity, and adaptability evident in a developmental culture. Moreover, this emphasis on employee growth and development in a developmental culture would keep employees motivated and committed to the organization (MacIntosh \& Doherty, 2010). We therefore propose:

Hypothesis 1b: Developmental culture mediates the relationship between transformational leadership and employee affective organizational commitment.

\section{Organizational Culture as a Mediator Between Transformational Leadership and Turnover Intentions}

Organizational turnover can result in severe negative consequences for an organization (Watrous, Huffman, \& Pritchard, 2006). Voluntary organizational turnover, or a process in which an individual makes a decision to stay or leave the firm (McPherson, 1976), is often dysfunctional and can be the most detrimental to the organization (Mobley, 1982). However, an employee's intention to leave an organization may be the more valuable outcome to assess (Harris, Kacmar, \& Witt, 2005). Scholars have determined that behavioral intentions are the single best predictor of turnover, and have thus used turnover intentions as a proxy for actual turnover (Egan, Yang, \& Bartlett, 2004). Indeed, transformational leadership is an important factor in mitigating turnover intentions (Hughes, Avey, \& Nixon, 2010; Martin \& Epitropaki, 2001; Tse \& Lam, 2008; Wells \& Welty Peachey, 2011).

Subordinates can perceive behaviors displayed by leaders as indicators of organizational intentions (Levinson, 1965). Transformational leaders create a vision and foster pride and a sense of belonging to the organization, and communicate why membership in the organization is important, enabling employees to internalize organizational values (Bass, 1985). Transformational leadership encourages an emotional attachment to the leader among followers, and can foster high levels of trust (Tse \& Lam, 2008). Thus, leaving the organization could have a high cost for followers, as they may not wish to disengage from this quality relationship.

Variation in employee retention rates across organizations may be related to organizational culture, as these values influence human resource strategies (selection and placement, promotion, development, reward systems), as well as the psychological climate of the organization (Kopelman, Brief, \& Guzzo, 1990). MacIntosh and Doherty (2005) found subculture strength was negatively related to turnover intentions among employees in the fitness industry, and subcultures that valued trust, care, growth, and innovation had less staff turnover. A later study demonstrated organizational cultures that fostered connectedness and cutting-edge programming were negatively associated with employee turnover intentions, while organizational cultures that emphasized formalization and rules were positively associated with turnover intentions (MacIntosh \& Doherty, 2010). However, 
in a subsequent study, organizational culture did not serve as an antecedent to employee turnover when job satisfaction was considered in the model (MacIntosh $\&$ Walker, 2012).

With regards to the current study, we contend athletic directors who are transformational leaders will provide employees with individualized consideration, listening to the needs and concerns of employees, and provide supportive environments to foster employee growth and development (Bass \& Avolio, 2000). This, in turn, will enhance the values espoused in a group culture, including social support and teamwork, which would reduce employees' intentions to voluntarily leave the organization (MacIntosh \& Doherty, 2010). Therefore, we propose the following hypothesis:

Hypothesis 2a: Group culture mediates the relationship between transformational leadership and employee voluntary turnover intentions.

Also, an athletic director acting as a transformational leader will encourage employees to be creative and innovative, and challenge employees' beliefs and values (Welty Peachey et al., 2011). This type of leadership will support the values of autonomy, stimulation, and adaptability evident in a developmental culture, which would reduce employee turnover intentions by providing an engaging and exciting work environment. Therefore, we propose the following hypothesis:

Hypothesis 2b: Developmental culture mediates the relationship between transformational leadership and employee voluntary turnover intentions.

\section{Organizational Culture as a Mediator Between Transformational Leadership and Job Search Behaviors}

As described in the previous section, transformational leadership behaviors and organizational culture can influence an employee's intention to leave an organization. Job search behaviors are considered an additional antecedent to employee turnover intentions (Bretz, Boudreau, \& Judge, 1994). Job search behaviors and turnover intentions are related but are unique constructs in relation to organizational outcomes (Bretz et al., 1994). Job search behaviors are important to examine even if such behavior does not lead to voluntary employee turnover, as there are costs associated with such behaviors including time loss and energy shifted away from other work, as well as the development of thoughts reducing commitment to the organization (Bretz et al., 1994).

Two forces, push and pull, have been identified as influences on job search behaviors. Push factors are factors related to the context of the organization, while pull factors are those factors external to the organization. Bretz el al. (1994) explained push factors are those work or life factors that "cause significant discomfort or dissatisfaction to warrant generation and evaluation of alternatives" (p. 279). Push factors influencing job search behaviors could include relationships with leaders, affective organizational commitment, job satisfaction, and job stress. Conversely, pull factors are defined as "costs or difficulties of searching in relation to the probability of finding a new position" (Bretz et al., 1994, p. 280). Therefore, pull factors have an influence on job search behaviors if an employee's upward mobility in an organization makes that employee a target for external recruitment; 
therefore the costs of looking for a new position are low in relation to securing that new position. External opportunities for advancement and more enticing job prospects in other organizations are pull factors influencing job search behaviors (Bretz et al., 1994; Harris et al., 2005).

In addition to the negative influence on turnover intentions, transformational leadership is also negatively related to an employee's job search behaviors. As described by Hughes and colleagues (2010), transformational leaders motivate and inspire employees and provide a sense of meaning to their work and therefore may lessen employee behaviors associated with job searching. As described earlier, organizational culture does have an influence on both an employee's affective organizational commitment and intentions to leave the organization. Following this logic, if job search behaviors are considered as a related but distinct construct from turnover intentions, organizational culture may have a similar influence on an employee's job search behaviors.

It makes conceptual sense to argue for the mediating role of organizational culture on the relationship between transformational leadership and job search behaviors. Again, if an athletic director is demonstrating transformational leadership behaviors and is motivating employees to become committed to the organization and providing supportive behaviors to help the employee move through personal and professional challenges, this type of leadership will support the values of teamwork and social support as espoused in a group culture. Employees may then be less likely to search for alternate employment. Therefore we propose the following hypothesis:

Hypothesis 3a: Group culture mediates the relationship between transformational leadership and employee job search behaviors.

Finally, by demonstrating transformational leadership behavior, an athletic director will again challenge employees to be creative and innovative, supporting the values of autonomy, stimulation, and adaptability espoused in a developmental culture. We propose the following hypothesis:

Hypothesis 3b: Developmental culture mediates the relationship between transformational leadership and employee job search behaviors.

\section{Method}

\section{Participants}

Participants were 83 female and 103 male ( $n=188$, two participants did not indicate sex on the survey) athletic administrators working in NCAA Division I intercollegiate athletic departments. Participants worked in their current positions between one and five years (47\%), six to ten years (24\%), 11-15 years (13\%), $16-20$ years $(7 \%)$, and more than 20 years $(9 \%)$. A majority of participants selfidentified as White $(n=170,89 \%)$. They worked as associate athletic director $(n$ $=81,43 \%)$, assistant athletic director $(n=36,18.9 \%)$, senior woman administrator $(n=14,7.4 \%)$, director of marketing $(n=15,7.7 \%)$, director of compliance $(n=14,7.4 \%)$, director of academic advising $(n=22,11.6 \%)$, or director of life skills $(n=8,4.2 \%)$. 


\section{Measures}

The independent variables examined were perceptions of transformational leadership of the athletic director and perceptions of culture type from the CVF. Dependent variables measured included affective organizational commitment, turnover intentions, and job search behaviors (Table 1).

\section{Table 1 Measurement Model (Standardized Estimates)}

\begin{tabular}{|c|c|c|c|}
\hline Factor and Items & $\begin{array}{l}\text { Loadings } \\
\text { (b) }\end{array}$ & $\mathrm{I}-\mathrm{T}$ & $\alpha$ \\
\hline Transformational Leadership & & & .93 \\
\hline Inspirational Motivation & .82 & .79 & \\
\hline Individualized Consideration & .91 & .85 & \\
\hline Intellectual Stimulation & .81 & .78 & \\
\hline Idealized Influence—attitude & .91 & .87 & \\
\hline Idealized Influence_-behavior & .83 & .81 & \\
\hline Affective Organizational Commitment & & & .81 \\
\hline $\begin{array}{l}\text { This athletic department has a great deal of personal } \\
\text { meaning for me. }\end{array}$ & .81 & .74 & \\
\hline $\begin{array}{l}\text { I really feel a sense of belonging to my athletic } \\
\text { department. }\end{array}$ & .96 & .81 & \\
\hline $\begin{array}{l}\text { I really feel as if my athletic department's problems are } \\
\text { my own. }\end{array}$ & .40 & .37 & \\
\hline $\begin{array}{l}\text { I do not feel emotionally attached to my athletic } \\
\text { department. (Reverse) }\end{array}$ & .53 & .51 & \\
\hline $\begin{array}{l}\text { I do not feel like "part of the family" at my athletic } \\
\text { department. (Reverse) }\end{array}$ & .75 & .66 & \\
\hline Turnover Intention & & & .91 \\
\hline I intend to leave this athletic department soon. & .93 & .88 & \\
\hline $\begin{array}{l}\text { I plan to leave this athletic department in the next little } \\
\text { while. }\end{array}$ & .93 & .87 & \\
\hline I will quit this athletic department as soon as possible. & .71 & .65 & \\
\hline I may leave this athletic department before too long. & .77 & .73 & \\
\hline Job Search Behaviors & & & .86 \\
\hline $\begin{array}{l}\text { Reviewed job postings (online, professional association } \\
\text { postings, etc.) }\end{array}$ & .67 & .62 & \\
\hline Prepared or revised your resume. & .72 & .63 & \\
\hline $\begin{array}{l}\text { Read a book or article about getting a job or changing } \\
\text { jobs. }\end{array}$ & .57 & .56 & \\
\hline Talked with friends or relatives about possible leads. & .83 & .77 & \\
\hline
\end{tabular}




\begin{tabular}{|c|c|c|c|}
\hline Factor and Items & $\begin{array}{l}\text { Loadings } \\
\text { (b) }\end{array}$ & I-T & $\alpha$ \\
\hline $\begin{array}{l}\text { Spoke with previous employers or business acquaintances } \\
\text { about their knowing of potential jobs. }\end{array}$ & .85 & .76 & \\
\hline $\begin{array}{l}\text { Used current within the organization resources (e.g., } \\
\text { colleagues) to generate potential job leads. }\end{array}$ & .78 & .70 & \\
\hline Group Culture & & & .85 \\
\hline $\begin{array}{l}\text { This athletic department allows for participation and open } \\
\text { discussion. }\end{array}$ & .67 & .63 & \\
\hline This athletic department empowers employees to act. & .75 & 69 & \\
\hline $\begin{array}{l}\text { This athletic department assesses employee concerns and } \\
\text { ideas. }\end{array}$ & .83 & .73 & \\
\hline $\begin{array}{l}\text { This athletic department values human relations, } \\
\text { teamwork and cohesion. }\end{array}$ & .81 & .74 & \\
\hline Developmental Culture & & & .80 \\
\hline $\begin{array}{l}\text { This athletic department is very flexible, and follows a } \\
\text { decentralized leadership structure. }\end{array}$ & .54 & .45 & \\
\hline $\begin{array}{l}\text { This athletic department encourages creativity in problem } \\
\text { solving. }\end{array}$ & .84 & .76 & \\
\hline $\begin{array}{l}\text { This athletic department values organizational expansion, } \\
\text { growth, and development. }\end{array}$ & .74 & .63 & \\
\hline This athletic department values innovation and change. & .79 & .66 & \\
\hline
\end{tabular}

Note. I-T = Item-to-Total Correlations

Transformational leadership perceptions were measured using the Multifactor Leadership Questionnaire (MLQ) (MLQ_-Form 5×, Bass \& Avolio, 2000). Participants evaluated their athletic director's behavior on five, four-item MLQ subscales that measured different dimensions of transformational leadership behavior (i.e., idealized influence-attributes, idealized influence-behavior, inspirational motivation, intellectual stimulation, individualized consideration). Participants rated leader behavior on a five-point Likert-type scale ( 5 = frequently, if not always, to $1=$ not at all). We did not distinguish between the five MLQ leadership dimensions in this study as the subscales are highly correlated and are considered to constitute the higher order construct of transformational leadership (Avolio et al., 1999).

The eight CVF culture items, four items for group culture and four items for developmental culture type, were based on the competing values instrument II developed by Quinn and Spreitzer (1991). As mentioned previously, we did not include items assessing hierarchal or rational goals culture types because the literature suggests that a transformational leader would not establish and maintain these culture types, thus making an investigation of the mediating effect of hierarchal and rational goals cultures irrelevant (Lok et al., 2005). Following Colyer (2000), we modified the wording of the items so that they were relevant to an intercollegiate athletic context, but did not change the content assessed in each item (e.g., "group 
culture - participation, open discussion" was modified to "This athletic department allows for participation and open discussion"). Items assessed participants' perceptions of group and developmental cultures within their athletic departments. All items were measured using a five-point Likert scale $(5=$ strongly agree to 1 = strongly disagree) .

Participants evaluated their affective organizational commitment (Vandenberghe \& Bentein, 2009) to their athletic department using five items, and their turnover intentions with four items (Crossley, Bennett, Jex, \& Burnfield, 2007) on a five-point Likert scale $(5=$ strongly agree to $1=$ strongly disagree $)$. Job search behaviors were assessed (Blau, 1994) using six items evaluated on a five-point Likert-type scale $(5=$ at least ten times to $1=$ zero times $)$.

\section{Procedures}

Potential participants were contacted via e-mail and provided a link to an online survey. To obtain a sample of near 200 participants, we generated a random sample of 708 individuals to target a response rate of approximately $30 \%$. This random sample was obtained from a database of all individuals listed on the Division I intercollegiate athletic departments' websites $(N=1384)$ who were working as assistant or associate athletic administrators. These individuals were identified as potential study participants because they were most likely to report directly to the athletic director and thus able to assess the athletic director's leadership behavior.

Seven hundred eight prenotification emails were sent to participants indicating they would be invited to participate in an online survey. Seventy-six emails were returned for incorrect addresses, and 19 individuals indicated they had retired or changed positions. Two days following the prenotification e-mail, 613 valid emails were sent inviting participants to complete the online survey. A reminder e-mail was sent to participants seven days following the e-mail invitation, and a final reminder was sent seven days after the reminder e-mail. One hundred eighty-eight participants completed the online survey $(n=188)$ for a response rate of $30.6 \%$.

\section{Results}

Means, standard deviations, and bivariate correlations were calculated for all independent and dependent measures (Table 2). A confirmatory factor analysis (CFA) was conducted to assess the validity of the model and the discriminant validity of the individual constructs. Multivariate regression analysis was used to examine the effects of leadership and organizational culture on affective organizational commitment, turnover intentions, and job search behaviors.

The overall model statistics supported an adequate fit for the hypothesized model: $\chi^{2}(335)=627.9, p<.001$, RSMEA (root mean square of approximation) $=.067$, CFI (confirmatory fit index $)=.92$, TLI $($ Tucker Lewis index $)=.91$. The measures used for each construct indicated convergent validity (Table 1). To address issues of multicollinearity, we centered all variables before calculating the regression statistics (Aiken \& West, 1991). Multivariate regression analysis was used to evaluate the influence of perceptions of transformational leadership of participants' athletic directors and perceptions of organizational culture within participants' athletic departments on affective organizational commitment, turnover intention, 


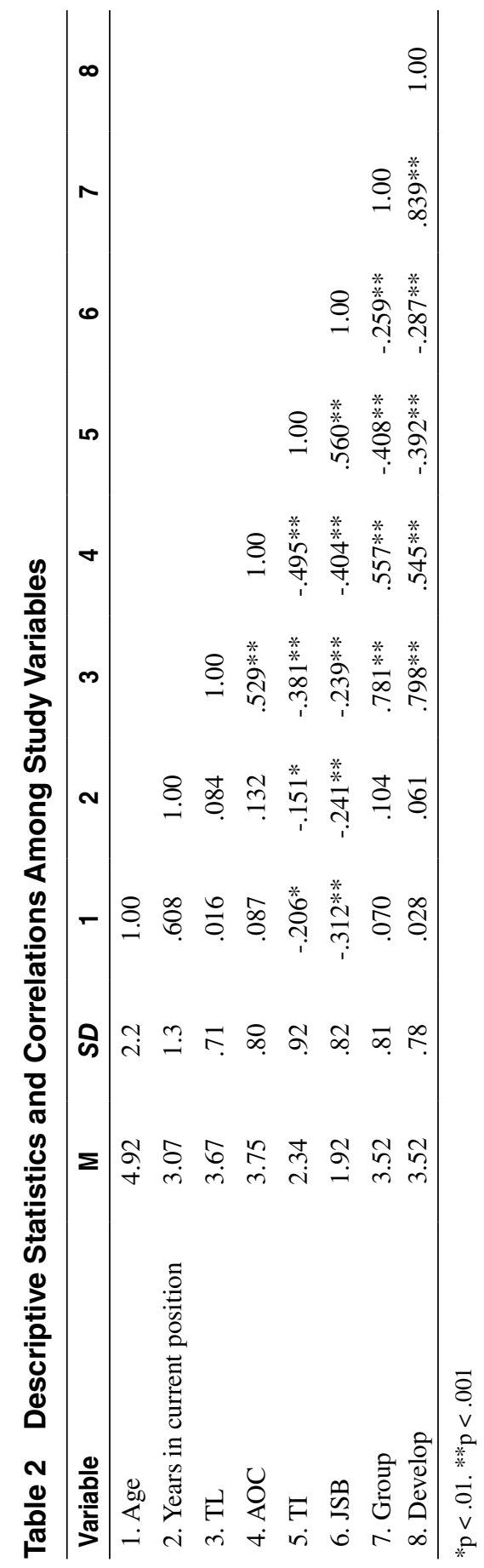


and job search behaviors. Participant age and years in current position were entered into the regression equations as control variables.

Following recommendations for analysis of mediation from Mathieu and Taylor (2006), we demonstrated discriminant validity of our measures before the mediation testing through the CFA described above. A precondition for tests of mediation is that the antecedent variable must "exhibit a significant total relationship with a criterion variable when considered alone" (Mathieu \& Taylor, 2006, p. 1037). Tables 3 and 4 demonstrate that this precondition was met. To test our

Table 3 Mediational analyses for Hypotheses $1 a-2 b$

\begin{tabular}{|c|c|c|c|}
\hline Path/effect & $\beta$ & SE & $\begin{array}{l}95 \% \text { Confidence } \\
\text { intervals }\end{array}$ \\
\hline \multicolumn{4}{|l|}{ Model 1} \\
\hline c (TransF $\rightarrow$ AffOrgCom) & $.58 * * *$ & .07 & \\
\hline $\mathrm{a}($ TransF $\rightarrow$ GroupCulture $)$ & $.90 * * *$ & .05 & \\
\hline $\mathrm{b}($ GroupCulture $\rightarrow$ AffOrgCom) & $.35 * * *$ & .10 & \\
\hline$c^{\prime}($ direct effect) & $.26^{*}$ & .11 & \\
\hline a x b (mediation effect) & $.32 * * *$ & .10 & $.126, .520$ \\
\hline \multicolumn{4}{|l|}{ Model 2} \\
\hline c (TransF $\rightarrow$ AffOrgCom) & $.58 * * *$ & .07 & \\
\hline $\mathrm{a}($ TransF $\rightarrow$ DevelopCulture $)$ & $.85^{* * *}$ & .05 & \\
\hline b(DevelopCulture $\rightarrow$ AffOrgCom) & $.33 * *$ & .10 & \\
\hline$c^{\prime}$ (direct effect) & $.31 * *$ & .11 & \\
\hline a $\times$ b (mediation effect) & $.31 * * *$ & .10 & $.082, .463$ \\
\hline \multicolumn{4}{|l|}{ Model 3} \\
\hline c (TransF $\rightarrow$ TurnoverIntent) & $-.47 * * *$ & .08 & \\
\hline a TransF $\rightarrow$ GroupCulture) & $.89 * * *$ & .05 & \\
\hline $\mathrm{b}($ GroupCulture $\rightarrow$ TurnoverIntent $)$ & $-.28 *$ & .12 & \\
\hline$c^{\prime}$ (direct effect) & -.23 & .14 & \\
\hline a $\times$ b (mediation effect) & $.18 * * *$ & .12 & $-.503,-.034$ \\
\hline \multicolumn{4}{|l|}{ Model 4} \\
\hline c (TransF $\rightarrow$ TurnoverIntent) & $-.47 * * *$ & .08 & \\
\hline $\mathrm{a}($ TransF $\rightarrow$ DevelopCulture $)$ & $.85^{* * *}$ & .05 & \\
\hline $\mathrm{b}($ DevelopCulture $\rightarrow$ TurnoverIntent $)$ & -.21 & .12 & \\
\hline$c^{\prime}$ (direct effect) & $-.30 *$ & .13 & \\
\hline $\mathrm{a} \times \mathrm{b}$ (mediation effect) & $.18^{* * *}$ & .11 & $-.389, .043$ \\
\hline
\end{tabular}


Table 4 Mediational analyses for Hypotheses $3 a-3 b$

\begin{tabular}{lccc}
\hline Path/effect & $\boldsymbol{\beta}$ & SE & $\begin{array}{c}\text { 95\% Confidence } \\
\text { intervals }\end{array}$ \\
\hline Model 5 & & & \\
c (TransF $\rightarrow$ JobSearch) & $-.26^{* * *}$ & .07 & \\
a(TransF $\rightarrow$ GroupCulture) & $.91^{* * *}$ & .05 & \\
b(GroupCulture $\rightarrow$ JobSearch) & $-.22^{*}$ & .11 & \\
c' (direct effect) & -.07 & .13 & \\
a x b (mediation effect) & $.15^{* * *}$ & .10 & $-.411,-.004$ \\
Model 6 & & & \\
c (TransF $\rightarrow$ JobSearch) & $-.26^{* * *}$ & .07 & \\
a(TransF $\rightarrow$ DevelopCulture) & $.85^{* * *}$ & .05 & \\
b(DevelopCulture $\rightarrow$ JobSearch) & -.18 & .11 & \\
c' (direct effect) & -.11 & .12 & \\
a x b (mediation effect) & $.15^{* * *}$ & .11 & $-.377, .052$ \\
\hline
\end{tabular}

hypotheses we used the INDIRECT program (Preacher \& Hayes, 2008) to compute confidence intervals based on an asymmetrical distribution of the mediated effect (Preacher \& Hayes, 2004).

Results of the hypotheses testing for Hypothesis $1 \mathrm{a}-2 \mathrm{~b}$ are shown in Table 3. In partial support of Hypothesis 1a (Model 1), the influence of the athletic director's transformational leadership behavior on affective organizational commitment remains significant, but is significantly reduced after controlling for group culture (i.e., the $95 \%$ confidence interval for the mediated effect does not include zero). The results for Model 1 show partial, but significant mediation. Hypothesis $1 \mathrm{~b}$ is partially supported (Model 2), as the influence of the athletic director's transformational leadership behavior on affective organizational commitment remains significant, but is significantly reduced after controlling for developmental culture (i.e., the $95 \%$ confidence interval for the mediated effect does not include zero). The results for Model 2 show partial, but significant mediation.

Model 3 fully supports Hypothesis 2a, as the influence of transformational leadership on turnover intentions is reduced to nonsignificant after including group culture, and the $95 \%$ confidence interval does not include zero, resulting in full mediation. Model 4 indicates no support for Hypotheses $2 \mathrm{~b}$, as developmental culture does not have a mediating effect; though the influence of transformational leadership is partially reduced, the $95 \%$ confidence interval for the mediated effect does include zero.

Hypotheses testing for $3 a-3 b$ are shown in Table 4 . Model 5 fully supports Hypothesis $3 \mathrm{a}$, as the influence of transformational leadership on job search behaviors is reduced to nonsignificant after including group culture, and the 95\% confidence interval does not include zero, resulting in full mediation. Model 6 indicates no support for Hypotheses $3 \mathrm{~b}$, as developmental culture does not have a 
mediating effect; though the influence of transformational leadership was reduced, the $95 \%$ confidence interval for the mediated effect does include zero.

\section{Discussion}

We sought to examine the gap in understanding how transformational leadership and organizational culture together influence organizational outcomes (i.e., affective organizational commitment, turnover intentions, job search behaviors) within the context of intercollegiate athletics. Specifically, we sought to better understand if group and developmental organizational culture types mediated the relationship between transformational leadership of the athletic director and the three organizational outcome variables. Overall, our findings lend additional support to the notion that the relationship between leadership and organizational culture has an effect on organizational outcomes (MacIntosh \& Doherty, 2010) and is an important area of study in intercollegiate athletics. Though we recognized a high correlation between group and developmental cultures (see Table 1), our findings indicate both cultures differentially impact the relationship between transformational leadership and the three organizational outcomes evaluated in this study.

We hypothesized group culture would mediate the relationship between transformational leadership and affective organizational commitment, which was partially supported in our analysis. Senior athletic administrators demonstrated affective organizational commitment when they worked for athletic directors who exhibited transformational leadership behaviors within an athletic department culture that valued employee development, teamwork, and employee involvement. This finding extends previous work regarding the influence of leadership behavior and organizational culture by demonstrating that transformational leadership behavior does work through group culture to influence employees' affective commitment to their organizations. Our findings support the work of Lok et al. (2005) indicating that leaders have a role in shaping the culture with which they are involved, which in turn affects employee's sense of affective commitment to their organization. However, our findings differ from Lok et al., as the influence of group culture serves only as a partial mediator within this context, reiterating the importance of leadership behavior as continuing to influence employees' affective commitment to their athletic department.

Our findings extend previous work that has identified the importance of a transformational leader's influence on affective organizational commitment in a sport organization (Choi et al., 2007; Kent \& Chelladurai, 2001). The findings demonstrate that transformational leadership directly influences affective organizational commitment. Further, our findings indicate that transformational leadership also works through group culture to affect affective organizational commitment, supporting initial work that indicated group cultures foster employee affective commitment to an organization (Lok \& Crawford, 1999; Lok et al., 2005; Silverthorne, 2004; Simosi \& Xenikou, 2010).

Within our findings, developmental culture partially mediated the relationship between transformational leadership and affective organizational commitment. The intellectual stimulation provided by transformational leaders would support employees trying new and innovative approaches to problem-solving and encourage risk-taking, tenets of a developmental culture that emphasize growth and 
development. As Lok et al. (2005) argued, an innovative culture may foster levels of stimulation and engagement that generate excitement and enhance commitment. Thus, our findings indicate that transformational leadership behavior demonstrated by the athletic director may help senior administrators to better understand how change and risk-taking within the developmental culture of the athletic department are related to their contributions to the organization and therefore foster increased affective organizational commitment.

Group culture fully mediated the relationship between transformational leadership and turnover intentions. The norms espoused in a group culture support the personal development of an employee and value employee attachment and affiliation to the organization. These norms, along with the inspirational motivation and individualized consideration provided by transformational athletic directors, also reduced participants' intentions to leave their organization. Our findings support the work of MacIntosh and Doherty $(2005,2010)$ who reported that within the fitness industry, organizational cultures that fostered connectedness were negatively associated with employee turnover intentions. A group culture can also provide this sense of connectedness and affiliation to the organization through its relational and team-building focus, which leads to a decreased desire to leave the organization. Thus, our study extends previous work in leadership and organizational culture by demonstrating that transformational leadership behavior acts to establish the values and norms associated with a group culture and then works through that established culture to influence turnover intentions. Group culture fully accounts for the influence of the leader and therefore becomes the primary influence on turnover intentions.

In addition, we found a developmental culture did not mediate the relationship between transformational leadership and turnover intentions. Though transformational leaders establish a developmental culture, the influence of the transformational leader continues to be a more significant influence on turnover intentions. Perhaps given the external orientation of a developmental culture and the focus on creativity and risk taking, transformational leadership, through individualized consideration, fosters trust and confidence on the part of employees. Therefore, transformational leadership is of greater importance in reducing turnover intentions in a developmental culture. Again, transformational leadership behavior, specifically intellectual stimulation demonstrated by the athletic director, may help senior administrators to better understand how change and risk taking within the developmental culture are related to their contributions to the organization and therefore have a more significant negative influence on their intentions to the leave their athletic departments than developmental culture. In addition, the relational focus (individualized consideration) of a transformational leader would ease any uncertainty or fears related to change and risk taking that may arise (Welty Peachey \& Bruening, 2011), and thus have a negative influence on turnover intentions. This finding can serve as a caution for those leaders seeking to develop a culture that emphasizes risk taking, in that they will also need to provide the supporting behaviors of transformational leadership to reduce turnover intentions.

We found that group culture fully mediates the relationship between transformational leadership and job search behaviors. This supports previous work that indicated if an employee evaluated organizational culture as having a positive influence in the organization (a positive push factor) there is less likelihood that he or she would begin preparatory job search behaviors (Bretz et al., 1994). Our participants 
may have perceived that the costs of looking for a new position were too high given the opportunities and experiences they were afforded in their current positions and the availability (or lack thereof) of other employment opportunities. Our findings extend previous work in leadership and organizational culture by demonstrating that transformational leadership behavior acts to establish the values and norms associated with a group culture and then works through that established culture to influence job search behaviors. Our findings suggest that a group culture accounts for the influence of the leader and therefore may become the primary influence on job search behaviors.

Finally, developmental culture did not mediate the relationship between transformational leadership and job search behaviors. Again, perhaps because of the external orientation of a developmental culture, one that values growth, risk-taking and autonomy, our participants were not receiving information that would have a negative influence on their exploration of alternative employment opportunities.

\section{Limitations}

There are limitations to this study that must be addressed. Our participant sample was limited by the accuracy of the database we developed for this study. The database was constructed using emails available on athletic department websites. Those websites may not have been up to date when the database was constructed, as 76 emails from our initial sample were returned for incorrect addresses or as a result of employee retirement. Further, this study was vulnerable to single source bias, which allowed for the possibility for contamination due to common method variance. Results of the validation of our measurement model indicate our study was not contaminated by common method variance (Podsakoff, MacKenzie, Lee, $\&$ Podsakoff, 2003). In addition, we measured intentions to leave the organization, not actual turnover behavior. However, we did attempt to measure both a cognitive (i.e., turnover intentions) and a behavioral (i.e., job search behaviors) component of intentions to leave (Hughes et al., 2010). Finally, our findings are only generalizable to senior level athletic administrators in the intercollegiate sport context. The influence of leadership behaviors and organizational culture may differentially impact lower level athletic administrators and graduate assistants within an athletic department, or vary in other sectors of the sport industry. Specifically, the leadership of a more proximal leader (as opposed to the athletic director) may have a more significant influence on the organizational outcomes measured in this study.

\section{Implications and Future Research Directions}

As our findings indicate, athletic directors should strive to cultivate a transformational leadership style and organizational culture that facilitates trust and values teamwork, employee involvement, and open communication. Such an organizational culture will foster affective organizational commitment, mitigate turnover intentions, and reduce job search behaviors, all of which can lead to increased organizational performance. In addition, athletic directors can foster a developmental culture to aid in affective organizational commitment.

Further research is needed to better understand if group culture mediates the relationship between transformational leadership and turnover intentions and job search behaviors in athletic departments in other NCAA Divisions and in other sport settings. Perhaps this relationship could vary based upon level of competition 
and organizational context. Further, it would be worthwhile to examine if group and developmental cultures serve as mediators between transformational leadership and other outcome variables such as individual effort, morale, and organizational performance (MacIntosh \& Doherty, 2010). This would aid in the development of a more robust theoretical model concerning the mediation effect of organizational culture on the relationship between transformational leadership and a broader array of outcome variables. Finally, proximal leaders (associate/assistant athletic directors or department directors) could establish subcultures that may either reinforce the dominant culture or have competing values to it (such as a hierarchal subculture in a dominant organizational group culture). It would be worthwhile to investigate the influence of proximal leadership and subcultures and ascertain how this influence may be different from the influence of the distal leader and dominant culture. Other scholars are invited to join us in these efforts.

\section{References}

Aiken, L.S., \& West, S.G. (1991). Multiple regression: Testing and interpreting interactions. Newbury Park, CA: Sage.

Avolio, B., Bass, B., \& Jung, D. (1999). Re-examining the components of transformational and transactional leadership using the Multifactor Leadership Questionnaire. Journal of Occupational and Organizational Psychology, 72, 441-462. doi:10.1348/096317999166789

Bass, B.M. (1985). Leadership and performance beyond expectations. New York: Free Press.

Bass, B.M. (1999). Two decades of research and development in transformational leadership. European Journal of Work and Organizational Psychology, 8(1), 9-32. doi:10.1080/135943299398410

Bass, B.M., \& Avolio, B.J. (1993). Transformational Leadership: A response to critiques. In M.M. Chemers \& R. Ayman (Eds.), Leadership theory and research: Perspectives and directions. Sydney: Academic Press Inc.

Bass, B.M., \& Avolio, B.J. (2000). Multifactor Leadership Questionnaire. Redwood City, CA: Mind Garden.

Blau, G. (1994). Testing a two-dimensional measure of job search behavior. Organizational Behavior and Human Decision Processes, 59, 288-312. doi:10.1006/obhd.1994.1061

Bretz, R.D., Boudreau, J.W., \& Judge, T.A. (1994). Job search behavior of employed managers. Personnel Psychology, 47, 275-301. doi:10.1111/j.1744-6570.1994.tb01725.x

Bryman, A. (1992). Charisma and leadership in organizations. London: Sage.

Burton, L.J., \& Peachey, J.W. (2009). Transactional or transformational? Leadership preferences of Division III athletic administrators. Journal of Intercollegiate Sport, 2, 245-259.

Cameron, K.S., Quinn, R.E., DeGraff, J., \& Thakor, A.V. (2006). Competing values leadership: Creating value in organizations. Northampton, MA: Edward Elgar Publishing.

Cascio, W.F. (2000). Costing human resources: The financial impact of behaviour in organizations. Boston, MA: Kent.

Choi, J., Sagas, M., Park, S., \& Cunningham, G.B. (2007). Transformational leadership in collegiate coaching: The effects of transformational leadership on job satisfaction, organizational commitment, and organizational citizenship behavior. International Journal of Sport Management, 8, 429-445.

Choi, Y.S., \& Scott, D.K. (2008). Assessing organizational culture using the competing values framework within American Triple-A baseball. International Journal of Sport Management and Marketing, 4, 33-48. doi:10.1504/IJSMM.2008.017657

Colyer, S. (2000). Organizational culture in selected Western Australia Sport Organizations. Journal of Sport Management, 14, 321-341. 
Crossley, C.D., Bennett, R.J., Jex, S.M., \& Burnfield, J.L. (2007). Development of a global measure of job embeddedness and integration into a traditional model of voluntary turnover. The Journal of Applied Psychology, 92, 1031-1042. PubMed doi:10.1037/00219010.92.4.1031

Cunningham, G.B., \& Sagas, M. (2004). People make the difference: The influence of the coaching staff's human capital and diversity on team performance. European Sport Management Quarterly, 4, 3-21. doi:10.1080/16184740408737464

Davis, D.J. (2002). An analysis of perceived leadership styles and levels of satisfaction of selected junior college athletic directors and head coaches. The Sport Journal, 5, 27-33.

Deal, T., \& Kennedy, A. (1988). Corporate cultures: The rites and rituals of corporate life. London: Penguin.

Doherty, A.J., \& Danylchuk, K.E. (1996). Transformational and transactional leadership in interuniversity athletic management. Journal of Sport Management, 10, 292-310.

Eagly, A.H., Johannesen-Schmidt, M.C., \& van Engen, M.L. (2003). Transformational, transactional, and laissez-faire leadership styles: A meta-analysis comparing women and men. Psychological Bulletin, 129, 569-591. PubMed doi:10.1037/0033-2909.129.4.569

Egan, T. M., Yang, B., \& Bartlett, K. R. (2004). The effects of organizational learning culture and job satisfaction on motivation to transfer learning and turnover intention. Human resource development quarterly, 15(3), 279-301.

Fulks, D.L. (2011). Revenues and expenses: NCAA Division I intercollegiate athletics programs report, 2004-2010. Indianapolis, IN: National Collegiate Athletic Association.

Harris, K.J., Kacmar, K.M., \& Witt, L.A. (2005). An examination of the curvilinear relationship between leader-member exchange and intent to turnover. Journal of Organizational Behavior, 26, 363-378. doi:10.1002/job.314

Hartnell, C.A., Ou, A.Y., \& Kinicki, A. (2011). Organizational culture and organizational effectiveness: A meta-analytic investigation of the competing values framework's theoretical suppositions. The Journal of Applied Psychology, 96, 677-694. PubMed doi:10.1037/a0021987

Hughes, L.W., Avey, J.B., \& Nixon, D.R. (2010). Relationship between leadership and followers quitting intentions and job search behaviour. Journal of Leadership \& Organizational Studies, 20, 1-12.

Judge, T.A., \& Piccolo, R.F. (2004). Transformational and transactional leadership: A metaanalytic test of their relative validity. The Journal of Applied Psychology, 89, 755-768. PubMed doi:10.1037/0021-9010.89.5.755

Kent, A., \& Chelladurai, P. (2001). Cascading transformational leadership, organizational commitment, and citizenship behavior: A case study in intercollegiate athletics. Journal of Sport Management, 15, 135-159.

Kent, A., \& Weese, W.J. (2000). Do effective organizations have better executive leaders and/or organizational cultures? A study of selected sport organizations in Canada. European Journal for Sport Management, 7, 4-21.

Klimoski, R.J., \& Koles, K.L. (2001). The chief executive officer and top management team interface. In S.J. Zaccaro \& R.J. Klimoski (Eds.), The nature of organizational leadership (pp. 219-269). San Francisco: Jossey-Bass.

Kopelman, R.E., Brief, A.P., \& Guzzo, R.A. (1990). The role of climate and culture in productivity. In B. Schneider (Ed.), Organizational climate and culture (pp. 282-318). San Francisco: Jossey-Bass.

Lawrence, H. (2013). The impact of intercollegiate athletics financial inequalities. Journal of Intercollegiate Sport, 6, 25-43.

Levinson, H. (1965). Reciprocation: The relationship between man and organization. Administrative Science Quarterly, 9, 370-390. doi:10.2307/2391032

Lok, P., \& Crawford, J. (1999). The relationship between commitment and organizational culture, subculture, leadership style and job satisfaction in organizational change and 
development. Leadership and Organization Development Journal, 20(7), 365-373. doi:10.1108/01437739910302524

Lok, P., Westwood, R., \& Crawford, J. (2005). Perceptions of organizational subculture and their significance for organizational commitment. Applied Psychology, 54, 490-514. doi:10.1111/j.1464-0597.2005.00222.x

MacIntosh, E.W., \& Doherty, A. (2005). Leader intentions and employee perceptions of organizational culture in a private ðtness corporation. European Sport Management Quarterly, 5, 1-22. doi:10.1080/16184740500089557

MacIntosh, E.W., \& Doherty, A. (2010). The influence of organizational culture on job satisfaction and intention to leave. Sport Management Review, 13, 106-117. doi:10.1016/j. smr.2009.04.006

MacIntosh, E.W., \& Walker, M.B. (2012). Chronicling the transient nature of fitness employees: An organizational culture perspective. Journal of Sport Management, 26, 113-126.

Martin, R., \& Epitropaki, O. (2001). Role of organizational identification on implicit leadership theories (ILTS), transformational leadership and work attitudes. Group Processes \& Intergroup Relations, 4, 247-262. doi:10.1177/1368430201004003005

Martinez, J.M., Stinson, J.L., \& Jubenville, C.B. (2011). Internal marketing perceptions in intercollegiate athletics and their influence on organizational commitment. Journal of Issues in Intercollegiate Athletics, 4, 171-189.

Mathieu, J.E., \& Taylor, S.R. (2006). Clarifying conditions and decision points for meditational type inferences in organizational behavior. Journal of Organizational Behavior, 27, 1031-1056. doi:10.1002/job.406

McPherson, B.D. (1976). Involuntary turnover and organizational effectiveness in the National Hockey League. In R.S. Gruneau \& J.G. Albinson (Eds.), Canadian sport: Sociological perspectives (pp. 259-275). Don Mills, Ontario: Addison-Wesley.

Meyer, J.P., \& Allen, N.J. (1991). A three-component conceptualization of organizational commitment. Human Resource Management Review, 1, 61-89. doi:10.1016/1053-4822(91)90011-Z

Mobley, W.H. (1982). Employee turnover, causes, consequences, and control. Reading, MA: Addison-Wesley.

O'Reilly, C.A., \& Chapman, J. (1996). Culture as social control: Corporations, cults, and commitment. Research in Organizational Behavior, 18, 157-200.

Podsakoff, P.M., MacKenzie, S.B., Lee, J.Y., \& Podsakoff, N.P. (2003). Common method biases in behavioral research: A critical review of the literature and recommended remedies. The Journal of Applied Psychology, 88, 879-903. PubMed doi:10.1037/00219010.88.5.879

Preacher, K.J., \& Hayes, A.F. (2004). SPSS and SAS procedures for estimating indirect effects in simple mediation models. Behavior Research Methods, Instruments, \& Computers, 36, 717-731. PubMed doi:10.3758/BF03206553

Preacher, K.J., \& Hayes, A.F. (2008). Asymptotic and resampling strategies for assessing and comparing indirect effects in multiple mediator models. Behavior Research Methods, 40, 879-891. PubMed doi:10.3758/BRM.40.3.879

Quinn, R.E., \& Rohrbaugh, J. (1983). A spatial model of effectiveness criteria: Towards a competing values approach to organizational analysis. Management Science, 29(3), 363-377. doi:10.1287/mnsc.29.3.363

Quinn, R.E., \& Spreitzer, G. M. (1991) The psychometrics of the competing values culture instrument and an analysis of the impact of organization culture on quality of life. In R. W. Woodman \& W. A. Pasmore (Eds.), Research in organization change and development, vol 5: 115-142. Greenwich, CT: JAI Press.

Rowold, J. (2006). Transformational and transactional leadership in martial arts. Journal of Applied Sport Psychology, 18, 312-325. doi:10.1080/10413200600944082

Schein, E. (1988). Organizational culture and leadership. San Francisco: Jossey-Bass. 
Schein, E. (1991). The role of the founder in the creation of organizational culture. In P.J. Frost, L.F. Moore, M.R. Louis, C.C. Lundberg, \& J. Martin (Eds.), Reframing organizational culture (pp. 14-25). Beverly Hills, CA: Sage.

Schein, E. (1992). Organizational culture and leadership. San Francisco: Jossey-Bass.

Schein, E.H. (1996). Culture: The missing concept in organization studies. Administrative Science Quarterly, 41, 229-240. doi:10.2307/2393715

Silverthorne, C. (2004). The impact of organizational culture and person-organization fit on organizational commitment and job satisfaction in Taiwan. Leadership and Organization Development Journal, 25, 592-599. doi:10.1108/01437730410561477

Simosi, M., \& Xenikou, A. (2010). The role of organizational culture in the relationship between leadership and organizational commitment: An empirical study in a Greek organization. International Journal of Human Resource Management, 10, 1598-1616. doi:10.1080/09585192.2010.500485

Smart, J.C., \& Wolfe, R.A. (2000). Examining sustainable competitive advantage in intercollegiate athletics: A resource-based view. Journal of Sport Management, 14, 133-153.

Tse, H.M., \& Lam, W. (2008). Transformational leadership and turnover: The roles of LMX and organizational commitment. Academy of Management Proceedings.

Vandenberghe, C., \& Bentein, K. (2009). A closer look at the relationship between affective commitment to supervisors and organizations and turnover. Psychological Journal of Occupational and Organizational Psychology, 82, 331-348. doi:10.1348/096317908X312641

Wallach, E. (1983). Individuals and organization: The cultural match. Training and Development Journal, 12, 28-36.

Wallace, M., \& Weese, W.J. (1995). Leadership, organizational culture, and job satisfaction in Canadian YMCA organizations. Journal of Sport Management, 9, 182-193.

Watrous, K.M., Huffman, A.H., \& Pritchard, R.D. (2006). When coworkers and managers quit: The effects of turnover and shared values on performance. Journal of Business and Psychology, 21, 103-126. doi:10.1007/s10869-005-9021-2

Weese, W.J. (1995). Leadership and organizational culture: An investigation of Big Ten and Mid-West American conference campus recreation administrations. Journal of Sport Management, 9, 119-134.

Wells, J.E., \& Welty Peachey, J. (2011). Turnover intentions: Do leadership behaviors and satisfaction with the leader matter? Team Performance Management, 17(1/2), 23-40. doi:10.1108/13527591111114693

Welty Peachey, J., \& Bruening, J. (2011). An examination of environmental forces driving change and stakeholder responses in a Football Championship Subdivision athletic department. Sport Management Review, 14, 202-219. doi:10.1016/j.smr.2010.09.002

Welty Peachey, J., Bruening, J., \& Burton, L.J. (2011). Transformational leadership of change: Success through valuing relationships in a Football Championship Subdivision athletic department. Journal of Contemporary Athletics, 5(2), 127-152.

Welty Peachey, J., \& Burton, L.J. (2011). Male or female athletic director? Exploring perceptions of leader effectiveness and a (potential) female leadership advantage with intercollegiate athletic directors. Sex Roles, 64, 416-425. doi:10.1007/s11199-010-9915-y

Wilkins, A.L. (1983). The culture audit: A tool for understanding organizations. Organizational Dynamics, 12(2), 24-38. doi:10.1016/0090-2616(83)90031-1

Woo, B., \& Chelladurai, P. (2012). Dynamics of perceived support and work attitudes: The case of fitness club employees. Dynamics (Pembroke, Ont.), 2(1), 6-18.

Xenikou, A., \& Simosi, M. (2006). Organizational culture and transformational leadership as predictors of business unit performance. Journal of Managerial Psychology, 21(6), 566-579. doi:10.1108/02683940610684409

Yusof, A., \& Shah, P.M. (2008). Transformational leadership and leadership substitutes in sports: Implications on coaches' job satisfaction. International Bulletin of Business Administration, 3, 17-29. 